\title{
Watery diarrhoea with a vasoactive intestinal peptide-producing ganglioneuroblastoma
}

\author{
YOSHIHIKO IIDA, OSAMU NOSE, HIROSHI KAI, AKIRA OKADA, TAKESADA MORI, \\ PAR-KHEN LEE, KENICHI KAKUDO, AND NOBORU YANAIHARA
}

Department of Paediatrics, First and Second Departments of Surgery, and First Department of Pathology, Osaka University Medical School, Osaka, and Laboratory of Bio-organic Chemistry, Shizuoka College of Pharmacy, Shizuoka, Japan

SUMMARY An 8-month-old boy with persistent watery diarrhoea and failure to thrive developed abdominal distension, hypokalaemia, and flushing of the face and trunk. A high concentration of vasoactive intestinal peptide-like immunoreactivity was found in the serum. Soon after resection of a suprarenal mass, the serum level of vasoactive intestinal peptide became normal and the diarrhoea stopped. Histologically the tumour was a ganglioneuroblastoma: the cells showed fluorescence by the indirect immunofluorescence technique with anti-vasoactive intestinal peptide serum. Electron microscopical examination showed abundant secretory granules in the tumour cells. Reports of chronic watery diarrhoea in children due to neural crest tumours are reviewed, with particular respect to the clinical features of the syndrome.

It is well known that a neural crest tumour should be considered in seeking the cause of unexplained chronic diarrhoea. ${ }^{1}$ In the past, catecholamines and related metabolites had been thought to be the causative agents of such diarrhoea, ${ }^{2-3}$ but this idea has now been abandoned. ${ }^{14-5}$ Recently it was proposed that vasoactive intestinal peptide (VIP) might be the cause of the watery diarrhoea syndrome $^{6-7}$ and that an increased plasma VIP concentration was diagnostic. ${ }^{8-9}$ In Bloom's series, ${ }^{10} 7$ of 39 patients with high concentrations of plasma VIP were found to have either a ganglioneuroma or a ganglioneuroblastoma. Only 5 children with the watery diarrhoea syndrome and increased VIP concentrations in the plasma or tumour tissue extracts ${ }^{11-15}$ have been reported. In one of them the location of the VIP-producing tumour was obscure, ${ }^{13}$ but each of the other 4 children had a ganglioneuroma or a ganglioneuroblastoma.

In 1975, we reported a typical case of the watery diarrhoea syndrome due to a ganglioneuroblastoma, but we did not measure the plasma VIP. ${ }^{16}$ We now report another such case, and suggest that the high level of serum VIP is the cause of the watery diarrhoea.

We also review reports of chronic diarrhoea in children with neural crest tumours, and discuss the clinical features useful in arriving at an early diagnosis of VIP-producing tumours.

\section{Case report}

An 8-month-old boy presented with protracted diarrhoea, abdominal distension, and failure to

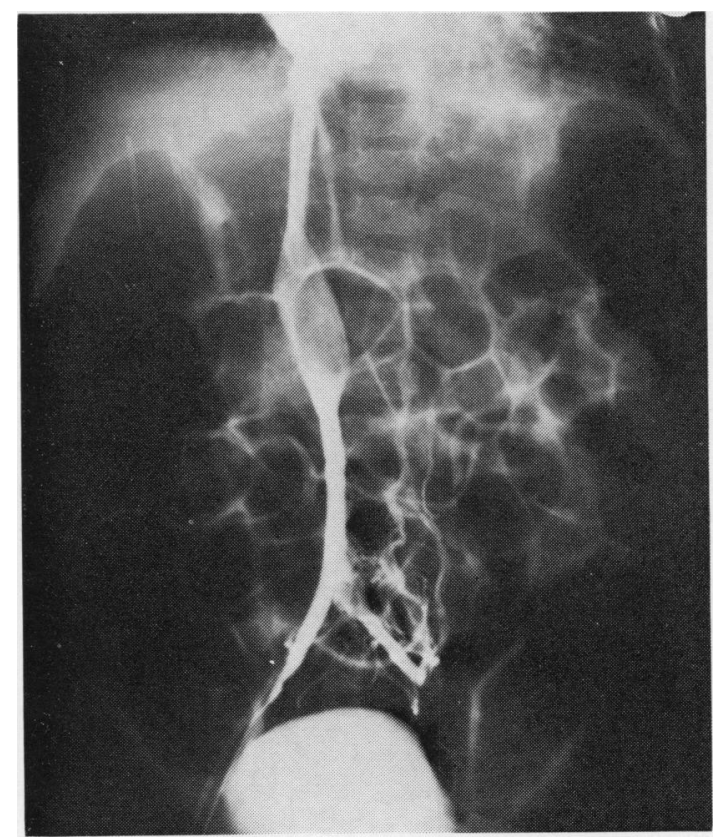

Fig. 1 The inferior vena cava is compressed by the tumour. 
thrive. He had been born after 35 weeks' gestation and had weighed $2.5 \mathrm{~kg}$ at birth. At 4 months his mother noticed abdominal distension. At 7 months watery diarrhoea began, and with abdominal distension and weight loss now severe, he was admitted to a local hospital. The diarrhoea persisted even during intravenous feeding. Hypokalaemia $(2.6 \mathrm{mmol} / \mathrm{l})$ and hyponatraemia $(126 \mathrm{mmol} / \mathrm{l})$ were noted. Lactose-free or soy feeds were ineffective. After 16 days he was transferred to our hospital.

On admission, he weighed $5 \cdot 3 \mathrm{~kg}$ and measured $64 \mathrm{~cm}$. He was poorly nourished, with moderate dehydration. Abdominal distension was pronounced and bowel sounds diminished. There was no palpable abdominal mass. His bowel movements, 5 to 8 times a day, were watery and brown and were not mixed with blood, mucus, or undigested food. He showed temporary flushing of the face and trunk, but blood pressure was normal $(110 / 70 \mathrm{mmHg})$.

Total parenteral nutrition for one week did not reduce the diarrhoea. Intravenous potassium sup- plements $(8-10 \mathrm{mmol} / \mathrm{kg}$ per day) were necessary to maintain normal serum potassium. Haematological values and erythrocyte sedimentation rate were normal. Serum analyses: sodium $134 \mathrm{mmol} / \mathrm{l}$, potassium $2.5 \mathrm{mmol} / \mathrm{l}$, chloride $105 \mathrm{mmol} / \mathrm{l}$, glucose $5.3 \mathrm{mmol} / 1(96 \mathrm{mg} / 100 \mathrm{ml})$, plasma urea $4 \mathrm{mg} / 100 \mathrm{ml}(1.43 \mathrm{mmol} / \mathrm{l})$, calcium $9.6 \mathrm{mg} / 100 \mathrm{ml}$ $(2 \cdot 4 \mathrm{mmol} / \mathrm{l})$, albumin $5.3 \mathrm{~g} / 100 \mathrm{ml}(53 \mathrm{~g} / \mathrm{l})$, total protein $7.6 \mathrm{~g} / 100 \mathrm{ml}(76 \mathrm{~g} / \mathrm{l})$. Serum concentrations of bilirubin, aspartate transaminase, and alanine transaminase were normal: lactic dehydrogenase was 774 units (normal, $<500$ units). No pathogenic bacteria were cultured from the faeces. A screening test for urinary vanillyl mandelic acid (VMA) was negative. Plain $x$-ray films of the abdomen showed amorphous calcifications in the right upper quadrant. A urogram located these calcifications in the right suprarenal area. Abdominal angiographs showed the existence of a suprarenal mass with moderate vascularity. The inferior vena cava was compressed by the tumour (Fig. 1).

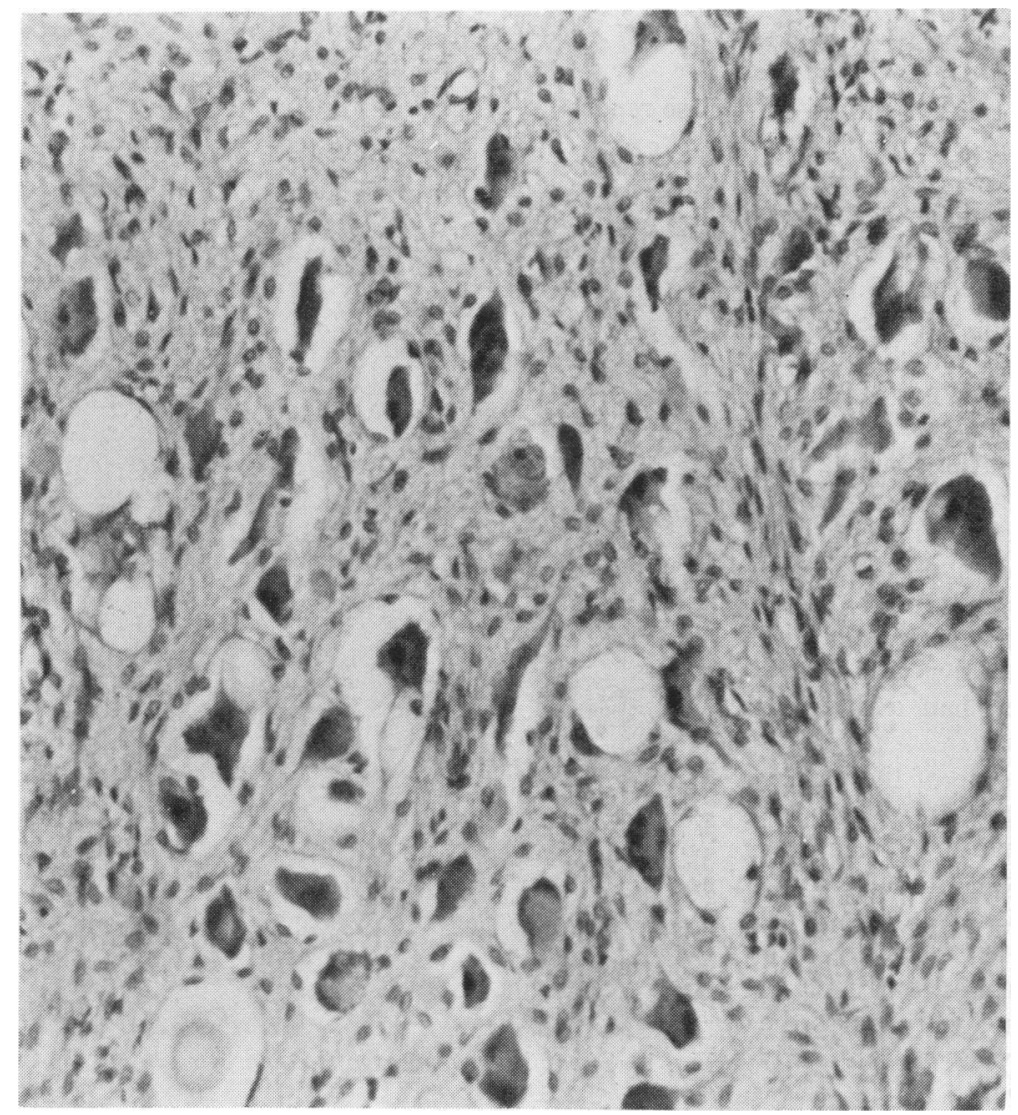

Fig. 2 Pure ganglionic cell area of well-differentiated ganglioneuroblastoma showing a collection of large ganglion cells and Schwann's sheath proliferation. 
Barium enema showed generalised dilatation of the colon. The serum VIP concentration was high (608 $\mathrm{pg} / \mathrm{ml}$ ).

On the 10th day after admission, laparotomy was performed and a $6.5 \times 3.5 \times 3.0 \mathrm{~cm}(40 \mathrm{~g})$ encapsulated solid tumour was removed completely. No abdominal metastasis was found. Soon after surgery the watery diarrhoea stopped and subsequently the weight gradually increased. Our patient is now 2 years old and progressing well.

\section{Methods}

Twenty-four hour urine specimens were collected and stored at $-20^{\circ} \mathrm{C}$. Urinary VMA and homovanillic acid (HVA) were measured by the methods of Pisano et al. ${ }^{17}$ and Ruthven and Sandler. ${ }^{18}$ Urinary catecholamines were measured by the method of Seki et al.,19 using high-speed liquid chromatography. Fasting serum immunoreactive VIP was assayed with antiserum (R-502) to synthetic porcine VIP.20

Fluorescence staining for immunohistological detection of VIP was performed by the indirect immunofluorescence technique with rabbit antiserum against synthetic porcine VIP as the first antibody, and fluorescein isothiocyanate-labelled

Table 1 24-hour urinary excretion of catecholamines and metabolites

\begin{tabular}{llcl}
\hline & \multicolumn{2}{l}{ Concentrations } \\
\cline { 2 - 4 } & Preoperative & Postoperative & Normal range* \\
\hline $\begin{array}{l}\text { Noradrenaline } \\
(\mu \mathrm{g} / 24 \mathrm{~h})\end{array}$ & 25.3 & 32.0 & $8.8 \pm 3.8$ \\
$\begin{array}{c}\text { Adrenaline } \\
(\mu \mathrm{g} / 24 \mathrm{~h})\end{array}$ & 0.3 & 2.6 & $1.8 \pm 1.4$ \\
$\begin{array}{l}\text { 4-Hydroxy-3-methoxy- } \\
\text { mandelate (mg/24h) }\end{array}$ & 2.1 & 1.4 & $1.3 \pm 0.6$ \\
$\begin{array}{l}\text { Dopamine } \\
(\mu \mathrm{g} / 24 \mathrm{~h})\end{array}$ & 272 & 100 & $71.0 \pm 35.5$ \\
$\begin{array}{l}\text { Homovanillic acid } \\
(\mathrm{mg} / 24 \mathrm{~h})\end{array}$ & 6.1 & 2.4 & $1.4 \pm 0.7$ \\
\hline
\end{tabular}

* Normal range: De Schaepdryver et al. 38

Conversion: traditional units to SI-4-hydroxy 3-methoxymandelate $1 \mathrm{mg} / 24 \mathrm{~h} \approx 5.05 \mu \mathrm{mol} / 24 \mathrm{~h}$.

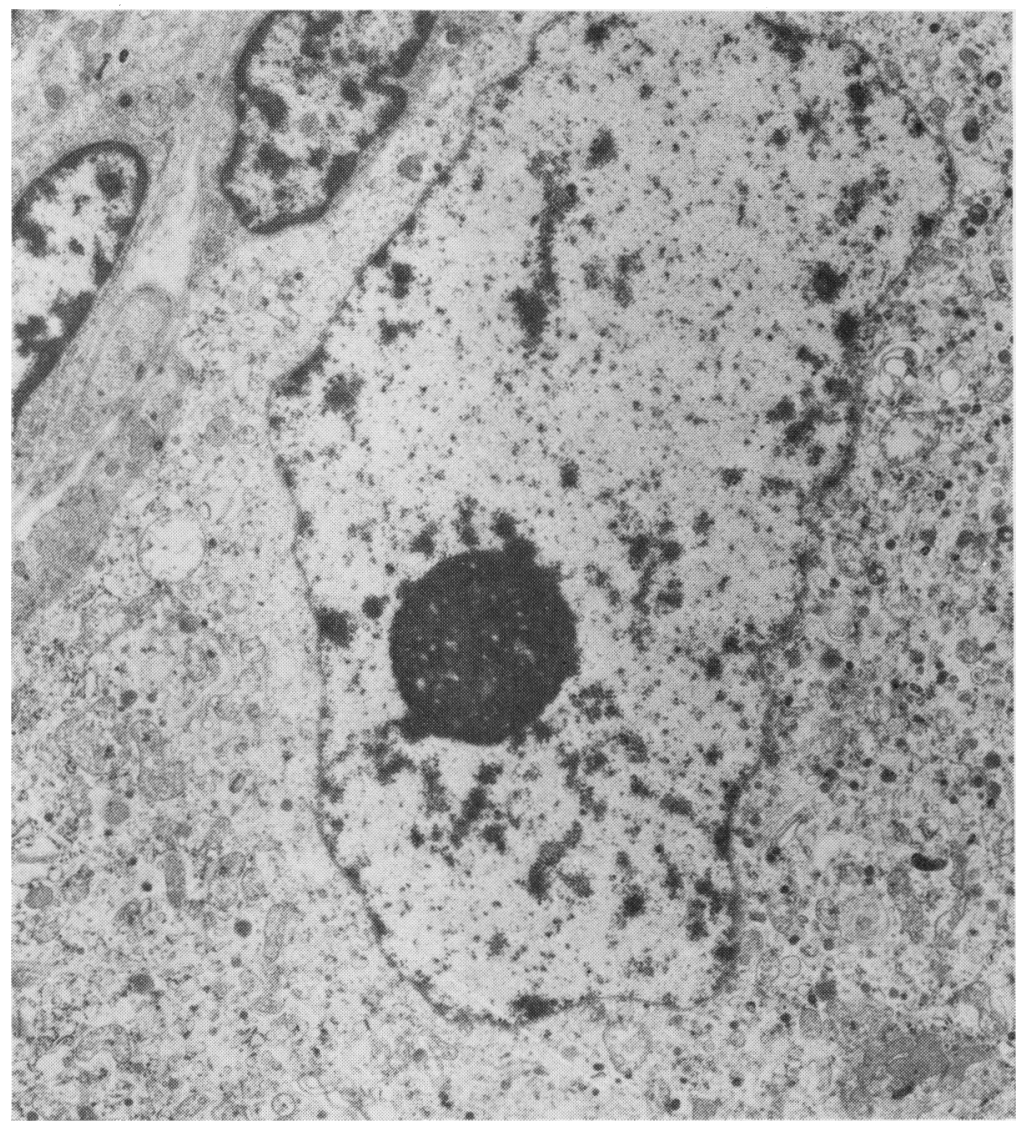

Fig. 3 Electron micrograph of a ganglionic giant cell showing a large nucleus with prominent nuclei and many secretory granules in the cytoplasm. $(\times 3000)$. 
goat anti-rabbit IgG antiserum as the second antibody.

\section{Results}

Twenty-four hour urinary excretion of catecholamines and their metabolites is shown in Table 1. The preoperative levels of dopamine and HVA were moderately high, but these levels became normal after operation.

The serum immunoreactive VIP level $(608 \mathrm{pg} / \mathrm{ml})$ was high before operation. One hour after resection of the tumour, the VIP level had already fallen to $130 \mathrm{pg} / \mathrm{ml}$ (normal range for our laboratory 200 $\mathrm{pg} / \mathrm{ml}$ or less ${ }^{20}$ ), and the values 2 and 3 months after operation were both normal.

Histologically the tumour was a typical ganglioneuroblastoma. It consisted mainly of large ganglionlike cells with prominent nuclei and nucleoli. Some cells appeared to be poorly differentiated. They were dispersed in a loose stroma forming a fibrillary cobweb-like network (Fig. 2).

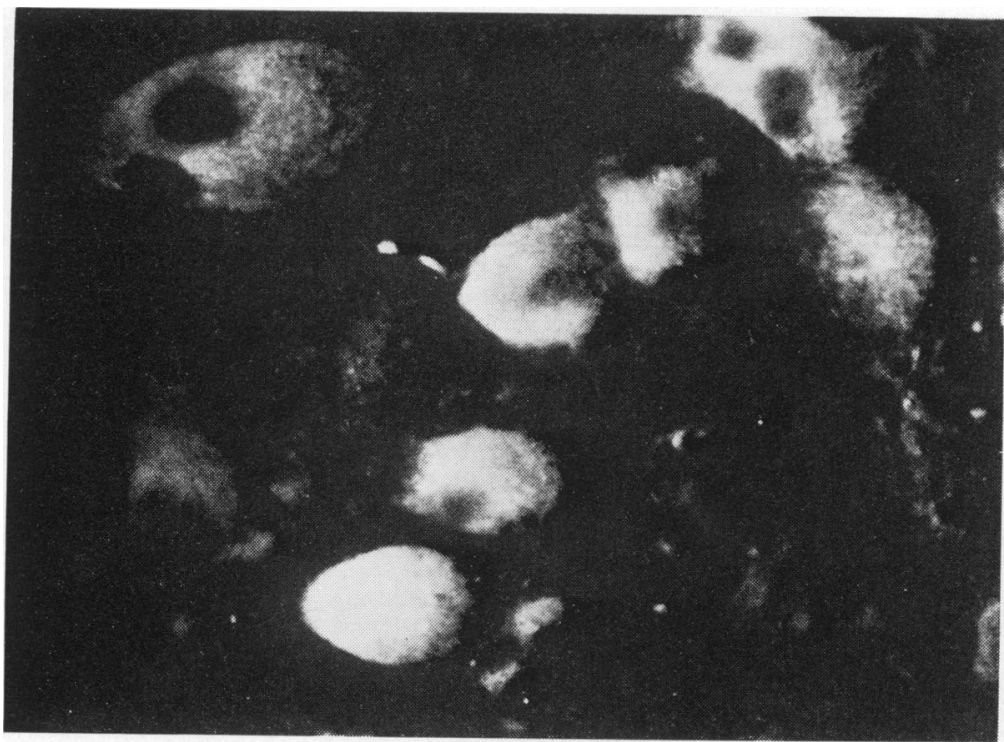

Fig. $4 \mathrm{a}$ Indirect immunofluorescence with highly specific rabbit antiserum against synthetic porcine VIP. Note that the specific fluorescence for VIP was observed diffusely in the cytoplasm of tumour cells. $(\times 400)$.

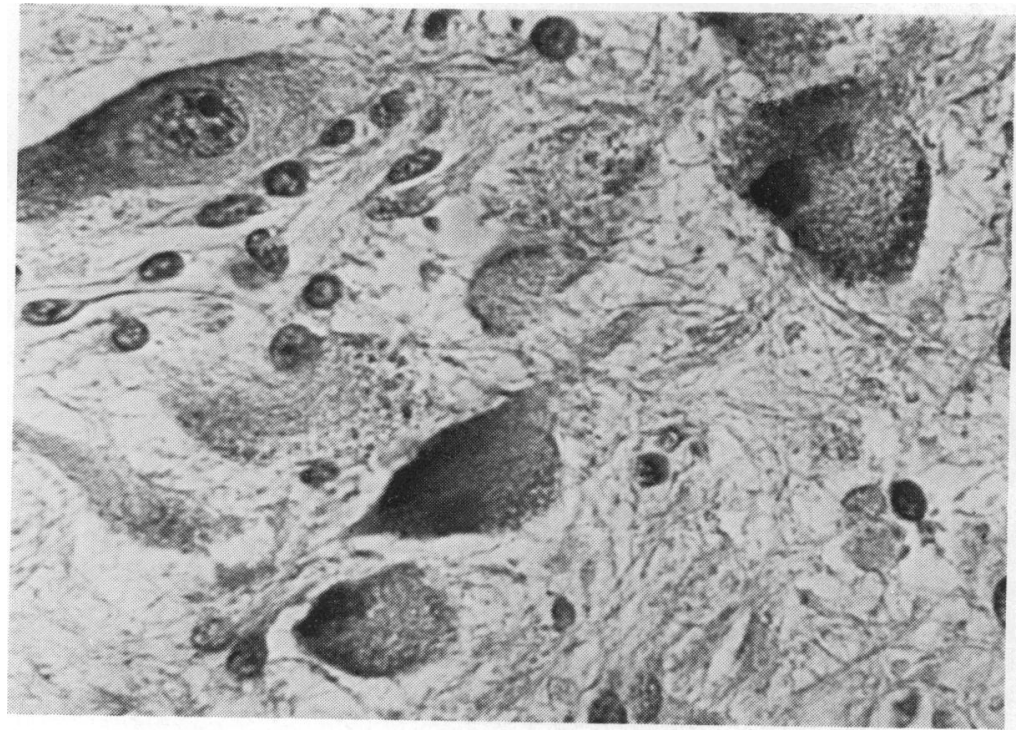

Fig. 4b Haematoxylin-eosin staining of section adjacent to Fig. 4a. The VIP-positive tumour cells have abundant acidophilic cytoplasm and a chromatin-rich nucleus. $(\times 400)$. 
Electron microscopical examination showed that most ganglionic tumour cells had a nucleus with a prominent nucleolus. The cells had abundant cytoplasm containing numerous organelles and many round or oval granules (Fig. 3). Among the large tumour cells there were many neurites with abundant neurotubules and various numbers of secretory granules and vesicles. In some areas of the plasma membrane of the neurites there were synapse-like structures.

Immunohistochemical studies with rabbit antiserum against synthetic porcine VIP showed specific fluorescence for VIP diffusely distributed in the cytoplasm of only certain tumour cells, which were clustered in restricted areas-that is, the VIPpositive tumour cells were not evenly dispersed. Histologically, these VIP-positive tumour cells had abundant, rather acidophilic cytoplasm, and much chromatin in the nucleus (Figs $4 a, b$ ).

\section{Discussion}

In the past, measurement of urinary catecholamines or metabolites has been recommended as the most useful aid in diagnosis of neural crest tumour. ${ }^{21}$ In many patients presenting with diarrhoea increased excretion of urinary catecholamines is present, but it is difficult to explain the diarrhoea simply as an effect of these substances, ${ }^{13-514}$ because not all patients who have such tumours and secrete large amounts of catecholamines do have diarrhoea. Again, patients with pheochromocytoma secrete large quantities of catecholamines, but rarely have diarrhoea as a main symptom. ${ }^{3}$

Recently, an increase in the concentration of VIP was noted in the plasma or tumour tissue of patients with the watery diarrhoea syndrome $e^{6-7} 10$ and it was proposed that VIP was the cause of this syndrome and that its measurement was of diagnostic value. ${ }^{8-10}$

VIP is a biologically-active polypeptide of 28 amino-acid residues, ${ }^{22}$ first isolated from hog small intestine by Said and Mutt ${ }^{23-24}$ in 1970. Of the various biological actions of VIP, the following seem to be especially important in the watery diarrhoea syndrome: (1) stimulation of adenylate cyclase activity and secretion of intestinal mucosa, ${ }^{25-26}$ (2) both splanchnic and systemic vasodilatation, ${ }^{23-24}$ and (3) inhibition of both pentagastrin- and histamine-stimulated gastric acid secretion. ${ }^{27-28}$ These effects could explain the clinical symptoms of this syndrome - such as severe refractory watery diarrhoea, hypokalaemia, flushing attacks, and achlorhydria. Besides these actions, VIP is reported to induce hyperglycaemia ${ }^{29}$ and hypercalcaemia. ${ }^{30} \mathrm{~A}$ VIP-producing tumour with the same features as our case was recently reported by Modlin et al. ${ }^{31}$
Recently, Modlin et al. ${ }^{9}$ showed that continuous infusion of VIP caused severe diarrhoea, flushing, and hypokalaemia in pigs, and that the resulting increase in the concentration of VIP serum was comparable with that found in humans with the watery diarrhoea-hypokalaemia-achlorhydria (WDHA) syndrome.

VIP may be the cause of many cases of watery diarrhoea, but not of all cases ${ }^{32}$ since some may be due to pancreatic polypeptide. ${ }^{33}$

With regard to early diagnosis, there are reports of only 5 children with this syndrome in whom the plasma or tumour VIP was measured. But the literature provides much other information on cases where diarrhoea in infants and children has been associated with a neurogenic tumour, which we have summarised in Table 2 . It seems that the following clinical features are important for diagnosis. (1) Age: although the syndrome is found in persons of all ages, ${ }^{34}$ it is more common in infants and young children (Table 2). In adults WDHA syndrome often seems to be due to a pancreatic tumour, whereas in children it is often due to a ganglioneuro(blast)ma or neuroblastoma. $^{34}$ (2) Chronic watery diarrhoea, which is refractory to diet and to total parenteral nutrition: bowel movements are not always frequent, and some patients have large fluid stools only once or twice a day. (3) Hypokalaemia: of 19 cases with records of serum potassium, 14 had hypokalaemia (Table 2). The hypokalaemia is not necessarily continuous, but occurs in repeated severe episodes $(1.4-3.7 \mathrm{mmol} / 1$ in Table 2). Supplementation with large quantities of potassium may be necessary. ${ }^{13-14}$ (4) Abdominal distension and colonic dilatation: distension is not necessarily due to hypokalaemia, ${ }^{3}$ but may rather be an effect of VIP. (5) Transient response to corticosteroids: there are few reports of administration of corticosteroids to patients with this syndrome, but in all those reported (6 reports in Table 2) transient improvement of the symptoms was noted. ${ }^{3-41215-1635}$ The reason for the effects is unknown, but the effect of corticosteroid could be a diagnostic aid. (6) Hypo- or achlorhydria and inhibition of gastric acid secretion: these symptoms have been reported frequently in adults with the WDHA syndrome, ${ }^{8}$ but only occasionally in children with this syndrome ${ }^{14}$ (7) Flushing: the frequency of the appearance of flushing or rash is not high, and indeed only 7 are shown in Table 2. However, flushing appears only transiently, and so is easily overlooked. In experiments on pigs by Modlin et al., ${ }^{9}$ flushing was noted in all. (8) Urinary excretion of catecholamines and their metabolites: catecholamines are not causative agents of the diarrhoea, and moreover they are not always increased in this syndrome. 13 of 21 cases in 
934 Iida, Nose, Kai, Okada, Mori, Lee, Kakudo, and Yanaihara

Table 231 reported cases of diarrhoea in association with neural crest tumours in children

\begin{tabular}{|c|c|c|c|c|c|c|c|c|c|c|c|}
\hline \multirow[t]{2}{*}{ Reference } & \multirow[t]{2}{*}{ Age } & \multirow[t]{2}{*}{$\operatorname{Sex}$} & \multirow{2}{*}{$\begin{array}{l}\text { Type of } \\
\text { tumour }\end{array}$} & \multirow[t]{2}{*}{ Location } & \multirow{2}{*}{$\begin{array}{l}\text { Urinary } \\
\text { VMA }\end{array}$} & \multirow{2}{*}{$\begin{array}{l}\text { Plasma or } \\
\text { tumour } \\
\text { VIP }\end{array}$} & \multirow{2}{*}{$\begin{array}{l}\text { Abdominal } \\
\text { distension }\end{array}$} & \multicolumn{4}{|c|}{ Symptoms and signs } \\
\hline & & & & & & & & $\begin{array}{l}\text { Hypoka- } \\
\text { aemia } \\
(\text { mmol/l) }\end{array}$ & $\begin{array}{l}\text { Flushing } \\
\text { or rash }\end{array}$ & $\begin{array}{l}\text { Hyper- } \\
\text { tension }\end{array}$ & $\begin{array}{l}\text { Other } \\
\text { symptoms } \\
\text { and signs }\end{array}$ \\
\hline $\begin{array}{l}\text { Hawfield and } \\
\text { Daisley }{ }^{39}\end{array}$ & 13 months & $\mathbf{F}$ & GN & Adrenal & & & + & & Flushing & 一 & \\
\hline $\begin{array}{l}\text { Uhlmann and } \\
\text { von Essen } 40\end{array}$ & $\begin{array}{l}3 \text { years } \\
10 \text { months }\end{array}$ & $\mathbf{F}$ & NB & $\begin{array}{l}\text { Adrenal } \\
\text { Adrenal }\end{array}$ & & & + & & & & \\
\hline Green et al. 41 & 27 months & $\mathbf{M}$ & GNB & $\begin{array}{l}\text { Adrenal } \\
\text { Mediastinal }\end{array}$ & & & + & $+(3 \cdot 1)$ & & 一 & $\begin{array}{l}\text { Profuse } \\
\text { sweating }\end{array}$ \\
\hline & 18 months & $\mathbf{M}$ & GN & Mediastinal & & & + & & Rash & - & $\begin{array}{l}\text { Profuse } \\
\text { sweating. } \\
\text { Waddling }\end{array}$ \\
\hline Kaser and von & 30 months & $\mathbf{F}$ & GN & Adrenal & & & + & $-(4 \cdot 7)$ & & - & gait \\
\hline $\begin{array}{l}\text { Studnitz }{ }^{37} \\
\text { Smellie and }\end{array}$ & 8 months & $\mathbf{M}$ & NB & Adrenal & Raised & & + & - & & - & \\
\hline Sandler ${ }^{42}$ & 31 months & $\mathbf{F}$ & GN & Mediastinal & Raised & & + & $+(2 \cdot 8)$ & & + & $\begin{array}{l}\text { Profuse } \\
\text { sweating }\end{array}$ \\
\hline Gardner 43 & $\begin{array}{l}13 \text { months } \\
13 \text { months }\end{array}$ & $\begin{array}{l}\mathbf{F} \\
\mathbf{F}\end{array}$ & $\begin{array}{l}\text { NB } \\
\text { GNB }\end{array}$ & $\begin{array}{c}\text { Abdominal } \\
\text { Bifurcation } \\
\text { of aorta }\end{array}$ & $\begin{array}{l}\text { Raised } \\
\text { Raised }\end{array}$ & & \pm & $+(3 \cdot 7)$ & $\begin{array}{c}\text { Flushing } \\
\text { Rash }\end{array}$ & \pm & \\
\hline $\begin{array}{l}\text { Leboeuf et al. }{ }^{44} \\
\text { Stickler et al. }\end{array}$ & $\begin{array}{r}3 \frac{1}{2} \text { years } \\
19 \text { months }\end{array}$ & $\begin{array}{l}\mathbf{M} \\
\mathbf{M}\end{array}$ & $\begin{array}{l}\text { GN } \\
\text { GNB }\end{array}$ & $\begin{array}{l}\text { Adrenal } \\
\text { Bifurcation } \\
\text { of aorta }\end{array}$ & $\begin{array}{l}\text { Raised } \\
\text { Raised }\end{array}$ & & $\begin{array}{l}+ \\
+\end{array}$ & $+\overline{(1 \cdot 4)}$ & Flushing & $\begin{array}{l}+ \\
+\end{array}$ & $\begin{array}{l}\text { Response to } \\
\text { to steroids }\end{array}$ \\
\hline $\begin{array}{l}\text { Voorhess and } \\
\text { and Gardner }\end{array}$ & 218 years & $\mathbf{M}$ & GN & $\begin{array}{l}\text { Sympath- } \\
\text { etic chain } \\
\text { at sacrum }\end{array}$ & Raised & & & & & & \\
\hline $\begin{array}{l}\text { Kontras } 45 \\
\text { Rosenstein and }\end{array}$ & 3 years & $\mathbf{F}$ & GN & Adrenal & Raised & & & & & + & \\
\hline & 15 months & $\mathbf{M}$ & GN & Adrenal & Raised & & + & $+(3 \cdot 4)$ & Flushing & - & \\
\hline $\begin{array}{l}\text { Shelley } 46 \\
\text { Sindhu and }\end{array}$ & $\begin{array}{l}7 \text { months } \\
15 \text { months }\end{array}$ & $\begin{array}{l}\mathbf{M} \\
\mathbf{M}\end{array}$ & $\begin{array}{l}\text { GN } \\
\text { GN }\end{array}$ & $\begin{array}{l}\text { Mediastinal } \\
\text { Adrenal }\end{array}$ & Raised & & & & Flushing & - & Polydypsia \\
\hline $\begin{array}{l}\text { Anderson } 47 \\
\text { Peterson and }\end{array}$ & 5 years & $\mathbf{M}$ & GN & Adrenal & & & + & & & - & \\
\hline Collins 5 & 4 years & $\mathbf{M}$ & GN & Adrenal & Not raised & & + & $+(2 \cdot 0)$ & & 一 & $\begin{array}{l}\text { Dilatation of } \\
\text { colon }\end{array}$ \\
\hline Hamilton et al. ${ }^{3}$ & 33 years & $\mathbf{M}$ & GN & Adrenal & Not raised & & + & $\stackrel{+}{+}$ & - & - & $\begin{array}{l}\text { Dilatation of } \\
\text { colon. } \\
\text { Response } \\
\text { to steroids. } \\
\text { Waddling }\end{array}$ \\
\hline Fregonese et al. 48 & 482 years & $\mathbf{M}$ & GNB & Adrenal & $\begin{array}{l}\text { Slightly } \\
\text { raised }\end{array}$ & & 一 & & & - & gait \\
\hline Galbert $^{1}$ & $\begin{array}{l}6 \text { years } \\
16 \text { months }\end{array}$ & $\begin{array}{l}\mathbf{M} \\
\mathbf{F}\end{array}$ & $\begin{array}{l}\text { NB } \\
\text { GNB }\end{array}$ & $\begin{array}{l}\text { Adrenal } \\
\text { Adrenal }\end{array}$ & Not raised & & $\begin{array}{l}+ \\
+\end{array}$ & - & & - & \\
\hline Williams et al. ${ }^{35}$ & 526 months & $\mathbf{F}$ & GNB & Mediastinal & Raised & & + & $+(2 \cdot 2)$ & & 一 & $\begin{array}{l}\text { Response to } \\
\text { steroids }\end{array}$ \\
\hline $\begin{array}{l}\text { Käser et al.49 } \\
\text { Okada et al.16}\end{array}$ & 21 months & $\begin{array}{l}\mathbf{F} \\
M\end{array}$ & $\begin{array}{l}\text { GNB } \\
\text { GNB }\end{array}$ & Adrenal & Not raised & & $\stackrel{+}{+}$ & $\begin{array}{l}+(1 \cdot 8) \\
+(2.0)\end{array}$ & 二 & $=$ & \\
\hline & & & & & Not raised & & & $+(2 \cdot 0)$ & - & - & $\begin{array}{l}\text { Dilatation of } \\
\text { colon. } \\
\text { Response } \\
\text { to steroids }\end{array}$ \\
\hline Swift et al.11 & 5 years & $\mathbf{F}$ & GN & Mediastinal & Raised & Raised & - & $-(4 \cdot 1)$ & - & - & $\begin{array}{l}\text { Profuse } \\
\text { sweating }\end{array}$ \\
\hline $\begin{array}{l}\text { Mitchell et al. }{ }^{12} \\
\text { Jansen-Goemans } \\
\text { and }\end{array}$ & 17 months & $\mathbf{F}$ & GNB & Adrenal & Not raised & Raised & + & + & - & 一 & $\begin{array}{l}\text { Response to } \\
\text { steroids }\end{array}$ \\
\hline Engelhardt14 & 17 months & $\mathbf{M}$ & GNB & Neck & & Raised & + & $+(2 \cdot 0)$ & - & - & $\begin{array}{l}\text { Dilatation of } \\
\text { colon. Inhi- } \\
\text { bition of } \\
\text { gastric acid } \\
\text { secretion }\end{array}$ \\
\hline $\begin{array}{l}\text { Leupold et al.15 } \\
\text { Iida et al. }\end{array}$ & 18 months & $\mathbf{M}$ & $\mathbf{G N}$ & Mediastinal & Not raised & $\begin{array}{l}\text { Raised } \\
\text { (tumour) }\end{array}$ & & $+(1 \cdot 7)$ & & & $\begin{array}{l}\text { Response to } \\
\text { steroids }\end{array}$ \\
\hline (this case) & 8 months & $\mathbf{M}$ & GNB & Adrenal & Not raised & Raised & + & $+(2 \cdot 6)$ & Flushing & - & $\begin{array}{l}\text { Profuse } \\
\text { sweating. } \\
\text { Dilatation } \\
\text { of colon }\end{array}$ \\
\hline
\end{tabular}


Table 2 showed increased urinary excretion of VMA, but 8 cases showed little or none. However, neurogenic tumours are often associated with abnormal excretion of catecholamines, and so it is important to measure urinary VMA. Measurement also of HVA and catecholamines (dopamine, noradrenalin, and adrenalin as well as VMA) would be somewhat more effective. (9) Measurement of plasma VIP: measurement of VIP in carefully preserved frozen plasma may prove to be a simple and reliable test for diagnosis of many cases of this syndrome. Considerable care is necessary during specimen collection and assay. VIP is rapidly destroyed by proteolytic enzymes because it has two basic amino-acid sequences that are particularly susceptible to trypsinlike enzymes. Blood should therefore be taken into a proteolytic enzyme inhibitor (aprotinin, 1000 kallikrein inhibitor units $/ \mathrm{ml}$ blood) and then rapidly centrifuged and the plasma should be frozen at $-20^{\circ} \mathrm{C}$ within 15 minutes of venepuncture. ${ }^{1034}$ (10) Detection of tumours: as seen in Table 2, the adrenal and neighbouring regions are the most common sites for tumours, followed by the mediastinum, so that pyelography and chest $x$-rays are necessary; these tumours frequently show calcification. Other techniques-such as computerised tomography scanning and angiography-may be indicated. (11) Other symptoms: profuse sweating ( 5 cases in Table 2$)$ and waddling gait $(2$ cases in Table 2) are sometimes present.

\section{References}

1 Galbert M W. Chronic diarrhea with ganglioneuroblastoma. Clin Pediatr (Phila) 1971 : 10: 476-9.

2 Kogut M D, Kaplan S A. Systemic manifestations of neurogenic tumors. J Pediatr 1962: 60: 694-704.

3 Hamilton J R, Radde I C, Johnson G. Diarrhea associated with adrenal ganglioneuroma; new findings related to the pathogenesis of diarrhea. Am J Med 1968; 44: 453-63.

4 Stickler G B, Hallenbeck G A, Flock E V, Rosevear J W. Catecholamines and diarrhea in ganglioneuroblastoma. Am J Dis Child 1962; 104: 598-604.

5 Peterson H D, Collins O D, III. Chronic diarrhea and failure to thrive secondary to ganglioneuroma. Arch Surg 1967; 95: 934-6.

- Bloom S R, Polak J M, Pearse A G E. Vasoactive intestinal peptide and watery-diarrhoea syndrome. Lancet 1973; ii: $14-6$.

7 Said S I, Faloona G R. Elevated plasma and tissue levels of vasoactive intestinal polypeptide in the waterydiarrhea syndrome due to pancreatic, bronchogenic, and other tumors. $N$ Engl J Med 1975; 293: 155-60.

8 Bloom S R, Polak J M. The role of VIP in pancreatic cholera. In: Thompson J C, ed. Gastrointestinal hormones. Austin, Texas: University of Texas Press, 1975: 635-42.

9 Modlin I M, Bloom S R, Mitchell S J. Experimental evidence for vasoactive intestinal peptide as the cause of the watery diarrhea syndrome. Gastroenterology 1978; 75: $1051-4$.

10 Bloom S R.VIP and watery diarrhoea.VI. In: Bloom S|R, ed. Gut hormones. London: Churchill Livingstone, 1978: 583-8.
11 Swift P G E, Bloom S R, Harris F. Watery diarrhoea and ganglioneuroma with secretion of vasoactive intestinal peptide. Arch Dis Child 1975; 50: 896-9.

12 Mitchell C H, Sinatra F R, Crast F W, Griffin R, Sunshine $P$. Intractable watery diarrhea, ganglioneuroblastoma, and vasoactive intestinal peptide. $J$ Pediatr 1976; 89: 593-5.

13 Udall J M, Singer D B, Huang C T L, Nichols B L, Ferry G D. Watery diarrhea and hypokalemia associated with increased plasma vasoactive intestinal peptide in a child. $J$ Pediatr 1976; 88: 819-21.

14 Jansen-Goemans A, Engelhardt J. Intractable diarrhea in a boy with vasoactive intestinal peptide-producing ganglioneuroblastoma. Pediatrics 1977; 59: 710-6.

15 Leupold D, Rösch U, Zölliner E, Poley J R. Chronische Diarrhoe, Ganglioneurom, und Vaso-active intestinal polypeptide (VIP). Monatsschr Kinderheilkd 1977; 125: 462-3.

16 Okada H, Shima J, Nose O, Iida Y. Diarrhea in a boy with a ganglioneuroblastoma diagnosed biochemically (in Japanese). Acta Pediatr Jpn 1975; 79: 413-9.

17 Pisano J J, Crout J R, Abraham D. Determination of 3-methoxy-4-hydroxymandelic acid in urine. Clin Chim Acta 1962; 7: 285-91.

18 Ruthven C R, Sandler M. An improved method for the estimation of homovanillic acid in human urine. Clin Chim Acta 1966; 14: 511-8.

19 Seki T, Wada H, Ogasawara S, Yamatodani A. A method for systemic determination of biogenic amines by column chromatography (abstract). Jpn J Pharmacol 1977; 27: Supplement, 24P.

20 Yanaihara N, Sakagami M, Sato H, et al. Immunological aspects of secretin, substance P, VIP. Gastroenterology 1977; 72: 803-10.

21 Voorhess M L, Gardner L I. Studies of catecholamine excretion by children with neural tumors. J Clin Endocrinol Metab 1962; 22: 126-33.

${ }^{22}$ Mutt V, Said S I. Structure of the porcine vasoactive intestinal octacosapeptide. Eur $J$ Biochem 1974; 42: 581-9.

${ }^{23}$ Said S I, Mutt V. Potent peripheral and splanchnic vasodilator peptide from normal gut. Nature 1970; 225: 863-4.

24 Said S I, Mutt V. Polypeptide with broad biological activity: isolation from small intestine. Science 1970; 169: 1217-8.

${ }^{25}$ Schwartz C J, Kimberg D V, Sheerin H E, Field M, Said $\mathrm{S}$ I. Vasoactive intestinal peptide stimulation of adenylate cyclase and active electrolyte seretion in intestinal mucosa. J Clin Invest 1974; 54: 536-44.

26 Barbezat G O, Grossman M I. Intestinal secretion: stimulation by peptides. Science $1971 ; 174: 422-4$.

27 Schorr B A, Said S I, Makhlouf G M. Inhibition of gastric secretion by synthetic vasointestinal peptide (VIP) (abstract). Clin Res 1974; 22: 23A.

28 Makhlouf G M, Said S I. The effect of vasoactive intestinal peptide (VIP) on digestive and hormonal function. In: Thompson J C, ed. Gastrointestinal hormones. Austin, Texas: University of Texas Press, 1975: 599-610.

29 Kerins C, Said I. Hyperglycemic and glycogenolytic effect of vasoactive intestinal polypeptide. Proc Soc Exp Biol Med 1973; 142: 1014-7.

30 Makhlouf G M, Said S I, Yau W M. Interplay of vasoactive intestinal peptide and synthetic VIP fragments with secretion and octapeptide of cholecystokinin on pancreatic and biliary secretion (abstract). Gastroenterology 1974; 66: 737.

31 Modlin I M, Bloom S R, Barnes A, Welbourn R B. Cure of intractable watery diarrhoea by excision of a vipoma. Br J Surg 1978; 65: 234-6. 
32 Ebeid A M, Fischer, J E. VIP and watery diarrhoea. II. In: Bloom S R, ed. Gut hormones. London: Churchill Livingstone, 1978: 574-5.

${ }^{33}$ Fahrenkrug J, Schaffalitzky de Muckadell O B. VIP and watery diarrhoea. III. In: Bloom S R, ed. Gut hormones. London: Churchill Livingstone, 1978: 576-7.

34 Modlin I M, Bloom S R. VIPomas and the watery diarrhoea syndrome. $S$ Afr Med J 1978; 54: 53-6.

35 Williams T H, House R F, Jr, Burgert E O, Jr, Lynn H B. Unusual manifestations of neuroblastoma: chronic diarrhea, polymyocloniaopsoclonus, and erythrocyte abnormalities. Cancer 1972; 29: 475-80.

${ }^{36}$ Rosenstein B J, Engelman K. Diarrhea in a child with a catecholamine-secreting ganglioneuroma: case report and review of the literature. J Pediatr 1963; 63: 217-26.

37 Käser $\mathbf{H}$, von Studnitz W. Urine of children with sympathetic tumors. Am J Dis Child 1961; 102: 199-204.

38 De Schaepdryver A F, Hooft C, Delbeke M J, Van den Noortgaete M. Urinary catecholamines and metabolites in children. $J$ Pediatr 1978; 93: 266-8.

39 Hawfield $\mathbf{H} \mathbf{H}$, Daisley G W, Jr. A report of a case of a functional adrenal ganglioneuroma. Clin Proc Children's Hosp (DC) 1952; 8: 98-105.

40 Uhlmann E M, von Essen C. Neuroblastoma (neuroblastoma sympatheticum). Pediatrics 1955 ; 15: 402-12.

41 Green M, Cooke R E, Lattanzi W. Occurrence of chronic diarrhea in three patients with ganglioneuromas. Pediatrics 1959; 23: 951-5.

42 Smellie J M, Sandler M. Secreting intrathoracic ganglioneuroma. Proc Roy Soc Med 1961 ; 54: 327-8.

43 Voorhess M L, Gardner L I. Urinary excretion of nore- pinephrine, epinephrine, and 3-methoxy-4-hydroxymandelic acid by children with neuroblastoma. J Clin Endocrinol Metab 1961; 21 : 321-5.

44 Leboeuf G, Eberlein W R, Steiker D D, Bongiovanni A M. Functioning ganglioneuroma, celiac syndrome, and renal acidosis. Am J Dis Child 1961 ; 102: 693-5.

45 Kontras S B. Urinary excretion of 3-methoxy-4-hydrooxymandelic acid in children with neuroblastoma. Cancer 1962; 15: 978-86.

${ }^{46}$ Greenfield L J, Shelley W M. The spectrum of neurogenic tumors of the sympathetic nervous system: maturation and adrenergic function. $J$ Nat Cancer Inst 1965; 35: 215-23.

47 Sindhu S, Anderson C M. Ganglioneuroma as a cause of diarrhoea and failure to thrive. Aust Paediatr $J$ 1965; 1: $56-60$.

48 Fregonese B, Cottafava F, Vignola G, Vigilone M, Romagnoli G. Tumori della cresta neurale con diarrea cronica. Minerva Pediatr 1969; 21 : 1699-704.

49 Käser H, Laguna Serrano C, Velasco Collazo J A, Reverte Blanch F. Ganglioneuroblastom bei einem Mädchen mit chronischem Durchfall und Hypokaliämie. Helv Paediatr Acta 1973; 28 : 485-.9.

Correspondence to Dr Yoshihiko Iida, Department of Paediatrics, Osaka University Hospital, Fukushima-ku, Osaka, Japan 553.

Received 2 October 1979 